\title{
USING STUDENTS' VOICE TOWARDS QUALITY IMPROVEMENT OF ANGOLAN SECONDARY PHYSIC CLASSES
}

\author{
Maria da Graça Breganha \\ INIDE - National Institute for Research and Development in Education, Angola \\ E-mail: mariadagraasoaresbreganha@yahoo.com.br \\ Betina da Silva Lopes \\ University of Aveiro, Portugal \\ University of Coimbra, Portugal \\ E-mail: blopes@ua.pt \\ Nilza Costa \\ University of Aveiro, Portugal \\ E-mail: nilzacosta@ua.pt
}

\begin{abstract}
Educational research points to similar learning experiences across different countries, in particular that physical science tends to be an unpopular discipline among students from secondary school. The use of students' voice to adapt curriculum and implement innovative teaching practice has been gaining relevance towards the effort of potentiating positive and meaningful learning experiences. The present research discusses the voice of 1139 Angolan students from one public school attending the first cycle of secondary education ( $7^{\text {th }}$ to $9^{\text {th }}$ grade) considering their physics classes. Students'voice was accessed through the application of a questionnaire which included open and closed questions, some in the format of statements requiring students to indicate their individual opinion. Descriptive statistics to ten specific aspects of their physics classes points to a global scenario of transmissive teaching and a lack of laboratorial and technological resources. Moreover, laboratorial work, suggested in national curriculum to cover topics in Physics, and students' involvement in assessment seems to decrease from $7^{\text {th }}$ to $9^{\text {th }}$ grade. Identified patterns revealed to be statistically significant. Based on these results three specific recommendations for educational stakeholders are presented. The consideration of students' voice in curriculum and school management is particularly innovative, not only but also for Angolan contexts and particularly relevant considering that the Angolan curriculum reform is presently under evaluation. Finally, educational researchers around the world may find relevant insights for their own educational challenges taking into account the milestones associated to the fourth goal of the Sustainable Development Goals, which is focused in assuring a quality education for all.
\end{abstract}

Keywords: Angola, physics classes, secondary education, students'voice, quality education.

\section{Introduction}

In order to improve teaching, learning and assessment processes (TL\&A) Angola initiated a curricular reform, in particular at secondary education, in 2001, which leads to the adoption of new curricula, new programs, textbooks and guidelines for TL\&A (GRA, 2001). Even though this reform is presently at its last stage focused on evaluating quality of the associated processes and outputs (MEA, 2008), only a few schools are being integrated in this process due to financial and human resources constraints. While it is globally acknowledged that Angola has made important progress towards the increase of students' enrolment in the last decade, there is 
Maria da Graça BREGANHA, Betina da SILVA LOPES, Nilza COSTA. Using students' voice towards quality improvement of Angolan secondary physic classes

\section{PROBLEMS \\ OF EDUCATION \\ IN THE $21^{\text {st }}$ CENTURY Vol. 76, No. 3, 2018 \\ 290}

actually no guarantee that this fact is leading to students' higher access to an educational quality system. How certain are we that more students in (side) schools means actually that more of them are experiencing positive and meaningful learning experience? In alignment with Arroio's (2015) recommendation, namely in focusing research on quality rather on quantity considering African educational contexts, the present research aims to contribute to the minimization of this uncertainty.

Considering that educational research in Angola is still scarce, the present research is focused in covering the learning experiences of Angolan students, whose voice seems not to be sufficiently taken into account and therefore not yet sufficiently integrated at individual and/or institutional practices and policies.

The relevance of the research is also evident in a broader context considering the fourth goal of the Sustainable Development Goals, which is focused in assuring a quality education for all. Within the Incheon Declaration the importance of greater students' involvement in the management of schools and in the definition of institutional and educational policies is highly emphasized (UNESCO, 2016).

The theoretical background underlying this research comes from literature focused on students' voices about the aims, content and methodologies of their schooling, which has been growing since the 1990s (Cook-Sather, 2006; Jenkins, 2006; Santos Gouw \& Vincenzo Bizzo, 2016). This topic of research has been challenging the dominant image of students as silent, passive recipients, and has been encompassed as research on 'student/pupil voice' (Cook-Sather 2006; Fluter, 2007).

\section{Research Focus}

This research draws on the central approach of 'listening to' and 'learning from' (Angolan) students considering the quality of teaching, learning and assessment in (physics) classes.

In the last decades research considering students' voices about the way they are taught has been growing (Santos Gouw \& Vincenzo Bizzo, 2016). The research has been focused on integrating what students think and feel about (science) classes and their learning into the management of educational problems. At a broader context, the emergence of 'students' voice' within the educational research can be seen as a response to the United Nations Convention on Children's Rights, which defends that every child has a right to express his/her opinion and that this opinion is taken into account in any matter or procedure affecting that child (Osler, 1994). In this sense students' voice has progressively become an important element in understanding teaching and schooling more generally (Mc Callum, Hargreaves \& Gipps, 2000). Students' voice has also been gaining relevance as an instrument for curriculum development promoting alignment with students' needs and interests, including in Physics Education, partly due to the relative unpopularity of physical science as a subject of advanced study (Jenkins, 2006; Osborne, Simon \& Collins, 2003).

Reviewed literature on students' voice, revealed that the majority of research lacks an evolutionary perspective (Jenkins, 2006) and that the most frequent research methods include questionnaires, personal interviews and focus groups where students are directly asked to express their opinion about specific topics (Oldfather, 1995; Jenkins, 2006). There are several projects focused on investigating students' voices about science, scientists and science classes, mainly through the application of multiple choice questionnaires/inventories. One of the most known initiatives is the Norwegian Project about Relevance of Science Education, in short ROSE Project (http://roseproject.no/), which involves the application of a questionnaire to students with an average age of 15 years. Data has already been collected from more than 40 countries including eight African countries (Sjoberg, \& Schreiner, 2010; Anderson, 2006), but not Angola. 
Maria da Graça BREGANHA, Betina da SILVA LOPES, Nilza COSTA. Using students' voice towards quality improvement of Angolan secondary physic classes

Indeed, despite the fact that Angola is struggling with similar problems considering the unpopularity of physics among secondary students (Chimbalandongo, 2015), an extensive literature review about research on science/physics education in Angola highlighted its scarceness, and particularly no study was identified on students' voices, despite its international relevance.

\section{Methodology of Research}

\section{National Background of Research}

Since the instauration of peace in 2002, Angola has been able to expand its educational systems (Liberato, 2014). According to national documentation (MEA, 2008, 2014), and since political stabilization, Angola has increased the number of schools in the country as well as the number of students' enrolment. According to national reports (MEA 2008, 2014), and considering the first cycle of secondary education $\left(7^{\text {th }}\right.$ to $9^{\text {th }}$ grade), the number of classrooms grew $382.5 \%$ from 2002 to 2013, and the number of enrolled students grew $220.8 \%$ from 2002 to 2008 (Figure 1).

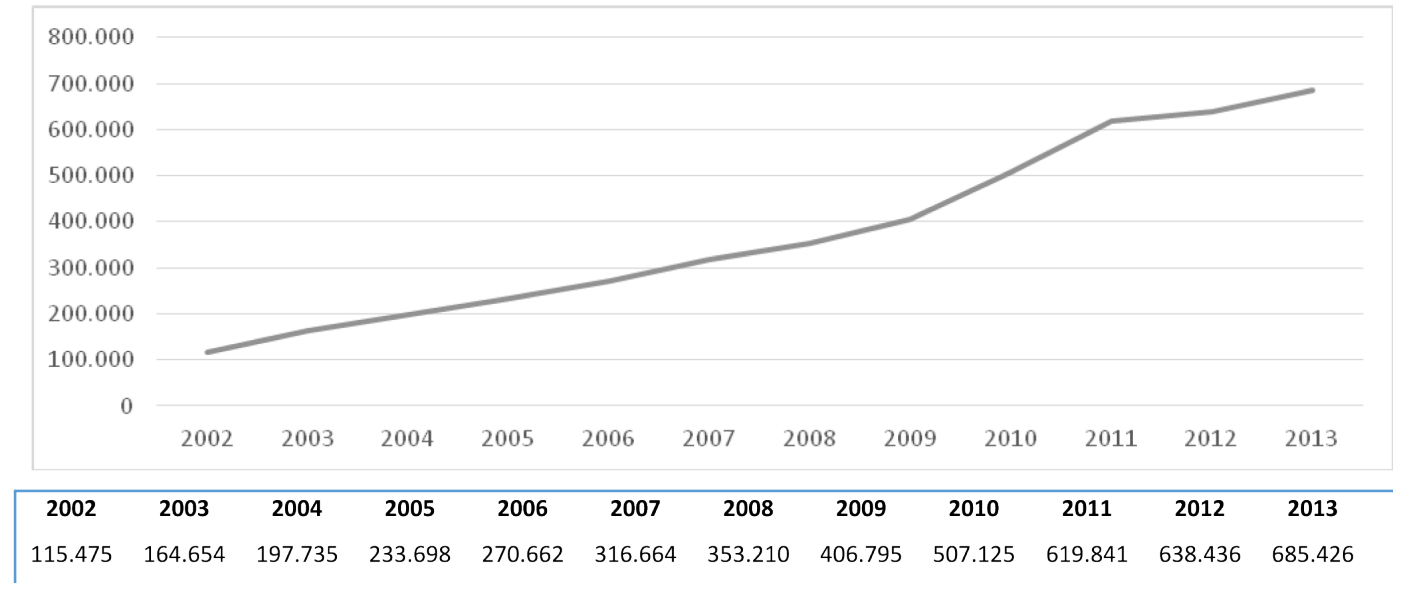
Figure1: Total number of Angolan students enrolled in the first cycle of secondary
education ( $7^{\text {th }}$ to $9^{\text {th }}$ grade) within the period of 2002 and $2008 .^{1}$

Currently, all the 18 provinces of the country offer first cycle secondary education. Despite accomplished progresses, continuing efforts and further investment are needed. The two presently major problems are the lack of infra-structures and equipment, such as school laboratories, as well as the lack of qualified teachers (MEA, 2014; Lopes, Costa, \& Matias, 2016) compromising the quality of the associated teaching, learning and assessment processes. On what concerns to infra-structures, national reports from the MEA recognize that classes still remain too big considering pedagogical aims adopted within the reform, indicating that, in general, classes have more than 40 students, particularly in urban areas (MEA, 2008, 2014). However, no official reference specifying how many classes have more than 40 students and exactly how many students integrate these classes was found. Calculations based on the statistical information available in report of 2008 (MEA, 2008) indicate that the smallest class may vary between 38-45 students, and that the size of the majority of classes may be above this number. In fact, other independent studies also report the existence of a high number of students per class, referencing classes with 70 to 100 students in some schools (Liberato, 2014; Delfin, 2014).

\begin{tabular}{l} 
PROBLEMS \\
OF EDUCATION \\
IN THE 21 $1^{\text {st }}$ CENTURY \\
Vol. 76, No. 3, 2018 \\
\hline 291
\end{tabular} 
Maria da Graça BREGANHA, Betina da SILVA LOPES, Nilza COSTA. Using students' voice towards quality improvement of Angolan secondary physic classes

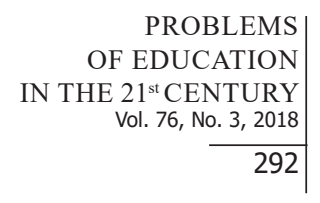

PROBLEMS

$21^{\text {st }}$ CENTURY

292

\section{Research Approach and Research Population}

This research is integrated in a broader case-study involving physics teachers and students from one public school of Lubango city. This city is located in the province of Huíla, has about 776.249 habitants, and a total of 54 public schools ministering classes from $7^{\text {th }}$ to $9^{\text {th }}$ grade (first cycle of secondary education) involving roughly 113.000 students $^{2}$.

The school was chosen by its historical background. This particular school was founded in order to allow displaced students, due to Angolan war, to complete their studies, even if they had already achieved the maximum age. This school is regionally referenced as being rooted in addressing students' rights and needs. The school is composed by five different associated buildings located in five different neighborhoods with a rough distance of 5-7 km between each one.

While the broader case-study involved multiple data gathering along three years (documental analysis, teacher interviews and students questionnaire) this particular research is focused on discussing the students' voices attending the school. It was aimed to cover all students enrolled in the first cycle of secondary education, namely 3994 students (Table 2), however, due to a high level of students' absenteeism it was only possibly to apply the questionnaire to 1149 students, $28.8 \%$ of the population. Moreover, from the total gathered questionnaires ten were excluded since they did not have enough information to be considered valid (more than $50.0 \%$ of non-answers). The final sample is therefore composed by 1139 students, 383 attending the 7th grade, 411 attending the $8^{\text {th }}$ grade and 345 students from the $9^{\text {th }}$ grade. The mean age of inquired students is 15.3 years. On what concerns to gender, $52.2 \%$ of the students are girls and $47.8 \%$ are boys.

Table 2. Distribution of students per school building and grade.

\begin{tabular}{|c|c|c|c|}
\hline School Building & Number of Students & & \\
\hline \multirow{4}{*}{ Head Building } & & $7^{\text {th }}$ & 400 \\
\hline & 983 & $8^{\text {th }}$ & 280 \\
\hline & & $9^{\text {th }}$ & 303 \\
\hline & & $7^{\text {th }}$ & 300 \\
\hline \multirow[t]{3}{*}{ Annex Building 1} & 738 & $8^{\text {th }}$ & 238 \\
\hline & & $9^{\text {th }}$ & 200 \\
\hline & & $7^{\text {th }}$ & 200 \\
\hline \multirow[t]{3}{*}{ Annex Building 2} & 420 & $8^{\text {th }}$ & 130 \\
\hline & & $9^{\text {th }}$ & 90 \\
\hline & & $7^{\text {th }}$ & 560 \\
\hline \multirow[t]{2}{*}{ Annex Building 3} & 1220 & $\begin{array}{l}8^{\text {th }} \\
9^{\text {th }}\end{array}$ & $\begin{array}{l}380 \\
280\end{array}$ \\
\hline & & $7^{\text {th }}$ & 230 \\
\hline \multirow[t]{3}{*}{ Annex Building 4} & 583 & $8^{\text {th }}$ & 203 \\
\hline & & $9^{\text {th }}$ & 150 \\
\hline & & $7^{\text {th }}$ & 1690 \\
\hline \multirow[t]{2}{*}{ Total } & 3944 & $8^{\text {th }}$ & 1231 \\
\hline & & $9^{\text {th }}$ & 1023 \\
\hline
\end{tabular}

2 Information available at: http://www.angop.ao/angola/pt_pt/noticias/educacao/2015/7/32/ Huila-Ministro-ensino-superior-destaca-papel-ISCED-formacao-quadros,ce83818c-9a3a-4759-959c1fd6a9b566e6.html; http://www.angop.ao/angola/pt_pt/noticias/educacao/2017/0/4/Huila-Professoresaguardam-por-reconversao-carreira,1611 fe6b-6c84-4e03-ae52-b40920858273.html 


\section{Instruments, Procedures \& Data Analysis}

Students' voice was gathered through their positioning on ten specific statements related to their physics classes by indicating their level of agreement (Total Agree/ "Concordo totalmente", Agree/ "Concordo" and Disagree/ "Discordo"). Notice that these statements emerged from updated international perspectives (Singh, 2014) and national curriculum guidelines (INIDE, 2012, 2013), both for physics education. A pilot-study was conducted previously with some students in order to identify conceptual and structural problems of the questionnaire. The following improvements were made: reduction of the number of open questions and closed questions, the use of a simplified three level agreement scale for the statements that required students' positioning, as referred to above. These adaptations were made because students revealed to have many difficulties in answering to the questionnaire, feeling unsecure and not being costumed to give their genuine opinion. Therefore, in the main study, the involved educational researchers invested considerable time in explaining to the students that they were answering to the questionnaire only for investigative purpose, that their answer was anonymous, that they could drop the research whenever they wanted and that it was important to express their genuine opinion and therefore they should not copy the answers of their colleagues.

On what concerns to data analysis procedures, descriptive and inferential statistical analysis was adopted using SPSS $®$ and STATA $®$.

\section{Results of Research}

Table 3 indicates students' positioning considering the ten specific statements related with their physics classes. First, a global view of the results is presented. Secondly, an evolutionary perspective will be elicited by comparing students' percentage with total agreement and disagreement at the beginning of the cycle ( $7^{\text {th }}$ grade) and at the end of the cycle ( $9^{\text {th }}$ grade).

\section{Global View}

Considering all the grades together, the three statements with higher percentage of total agreement were statement $5>$ statement $10>$ statement 8 , with $61.3>57.8>51.0 \%$ respectively. The three statements with higher percentage of disagreement were statement $9>$ statement $4>$ statement 1 , with $75.0>69.0>56.8 \%$ of disagreement respectively. The majority of students seem not to do laboratory work (statement 9) or use technological tools during their physics classes (statement 4). Furthermore, $56.8 \%$ of the inquired students considered that his/ her teacher does not relate the physics contents to other disciplines (statement 2). Students also seem not to ask questions during classes (statement 8 ) or participate in their assessment (statement 10). 
Maria da Graça BREGANHA, Betina da SILVA LOPES, Nilza COSTA. Using students' voice towards quality improvement of Angolan secondary physic classes

OF EDUCATION IN THE $21^{\text {st }}$ CENTURY Vol. 76, No. 3, 2018

\section{Table 3. Distribution of students' answers of all school levels and per grade.}

\begin{tabular}{|c|c|c|c|c|c|c|}
\hline Statements "In my Physic classes..." & $\mathrm{Ag}$ & ement Positioning & All grades & $7^{\text {th }}$ & $8^{\text {th }}$ & $9^{\text {th }}$ \\
\hline \multirow{3}{*}{$\begin{array}{l}\text { 1.... my teacher relates the physics subject to } \\
\text { those of other disciplines; }\end{array}$} & $\checkmark$ & Total Agree & 20.7 & 35.9 & 19.1 & 13.4 \\
\hline & & Agree & 22.5 & 15.7 & 20.9 & 24.7 \\
\hline & $X$ & Disagree & 56.8 & 48.4 & 59.9 & 61.9 \\
\hline \multirow{3}{*}{ 2. ... my teacher relates physics to everyday life; } & $\checkmark$ & Total Agree & 43.4 & 54.5 & 41.1 & 35.2 \\
\hline & & Agree & 36.2 & 28.3 & 37.6 & 42.5 \\
\hline & $X$ & Disagree & 20.4 & 17.3 & 21.3 & 22.3 \\
\hline \multirow{3}{*}{$\begin{array}{l}\text { 3. ... my teacher transmits contents by dictating } \\
\text { what is written in the school book; }\end{array}$} & $\checkmark$ & Total Agree & 50.0 & 59.3 & 55.7 & 42.0 \\
\hline & & Agree & 30.0 & 23.3 & 33.4 & 39.6 \\
\hline & $\mathrm{X}$ & Disagree & 20.0 & 17.4 & 10.9 & 18.4 \\
\hline \multirow{3}{*}{$\begin{array}{l}\text { 4. ... my teacher uses technological tools (e.g. } \\
\text { computers); }\end{array}$} & $\checkmark$ & Total Agree & 20.0 & 22.4 & 18.1 & 18.6 \\
\hline & & Agree & 11.0 & 6.2 & 12.7 & 14.9 \\
\hline & $X$ & Disagree & 69.0 & 71.5 & 69.2 & 66.5 \\
\hline \multirow{3}{*}{$\begin{array}{l}\text { 5.... my teacher solves the exercises on the board } \\
\text { and I copy to my notebook; }\end{array}$} & $\checkmark$ & Total Agree & 61.3 & 60.5 & 60.0 & 59.6 \\
\hline & & Agree & 26.7 & 20.9 & 25.7 & 33.0 \\
\hline & $X$ & Disagree & 12.0 & 18.6 & 10.3 & 7.4 \\
\hline \multirow{3}{*}{ 6. ... I solve exercises on the blackboard; } & $\checkmark$ & Total Agree & 48.5 & 58.4 & 52.0 & 38.3 \\
\hline & & Agree & 29.4 & 21.3 & 29.4 & 37.7 \\
\hline & $X$ & Disagree & 22.1 & 23.9 & 18.6 & 24.0 \\
\hline \multirow{3}{*}{ 7. ... I solve exercises in group with my colleagues; } & $\checkmark$ & Total Agree & 36.1 & 37.9 & 39.1 & 30.7 \\
\hline & & Agree & 27.1 & 18.9 & 28.6 & 34.0 \\
\hline & $X$ & Disagree & 36.8 & 43.2 & 32.2 & 35.2 \\
\hline \multirow{3}{*}{$\begin{array}{l}\text { 8. ... I participate in the class, by, for example, } \\
\text { raising doubts about what is being taught; }\end{array}$} & $\checkmark$ & Total Agree & 51.0 & 62.9 & 50.6 & 40.1 \\
\hline & & Agree & 35.0 & 26.0 & 35.8 & 43.7 \\
\hline & $X$ & Disagree & 14.0 & 11.1 & 13.6 & 16.2 \\
\hline \multirow{3}{*}{ 9. ... I realize laboratory work; } & $\checkmark$ & Total Agree & 13.2 & 17.7 & 13.1 & 8.8 \\
\hline & & Agree & 11.8 & 12.7 & 13.8 & 7.9 \\
\hline & $X$ & Disagree & 75.0 & 69.6 & 73.1 & 83.3 \\
\hline \multirow{3}{*}{$\begin{array}{l}10 . . . \text { my teacher asks the students to participate in } \\
\text { the assessment. }\end{array}$} & $\checkmark$ & Total Agree & 57.8 & 62.7 & 59.6 & 51.2 \\
\hline & & Agree & 31.0 & 21.4 & 31.6 & 40.1 \\
\hline & $X$ & Disagree & 11.2 & 15.9 & 8.8 & 8.7 \\
\hline
\end{tabular}

\section{Evolutionary Perspective}

Considering the lack of research on students' voice in an evolutionary perspective, the difference of total agreement percentages between $9^{\text {th }}$ and $7^{\text {th }}$ grade as well as the difference of disagreement percentages between $9^{\text {th }}$ and $7^{\text {th }}$ grade was calculated. Statements 8,9 and 10 were identified as those with higher percentage difference of students' positioning. According to the information of Table 3 it is possible to verify that from $7^{\text {th }}$ to $9^{\text {th }}$ grade statements 1 and 9 have disagreement which increases to $13.7 \%$ and $13.5 \%$, respectively. On the contrary, considering students' participation on assessment, which is the focus of statement 10, students' percentage with total agreement reduces $22.8 \%$ from $7^{\text {th }}$ grade $(62.7 \%)$ to $9^{\text {th }}$ grade $(51.2 \%)$. 
In order to support curriculum and classroom practices management of the involved school (institutional decision making), it was decided to confirm if the identified patterns are not just hypothesis, but also tendencies applicable to the population under study. Results of polychoric correlations confirmed the identified patterns for each of the statement, being those statistically significant:

- regarding statement 1 statistical analysis confirmed that the proportion of students who 'total agree' with it reduces significantly from $7^{\text {th }}$ to $9^{\text {th }}$ grade, $\chi^{2}(2)=37.253, p<.001$ whereas students who 'disagree' increased significantly, $\chi^{2}(2)=13.990, p<.001$. The polychoric correlation shows that the higher the level of schooling, the greater the disagreement with this statement (Polychoric rho $=.218$ );

- regarding statement 9 statistical analysis revealed that the proportion of students who 'total' agree with it reduces significantly from $7^{\text {th }}$ to $9^{\text {th }}$ grade, $\chi^{2}(2)=9.518, p<.05$, while students who 'disagree' with this statement increases significantly, $\chi^{2}(2)=8.100, p<.05$. The polychoric correlation shows that the higher the level of schooling, the greater the disagreement with this statement (Polychoric rho $=.191)$;

- regarding statement 8 statistical analysis confirmed that the proportion of students who 'total agree' reduces significantly from $7^{\text {th }}$ to $9^{\text {th }}$ grade, $\chi^{2}(2)=20.447, p<.001$, whereas students who 'disagree' increase, being this increase also statistically significant, $\chi^{2}(2)=3.507$, $\mathrm{p}=.173$. The results of the polychoric correlation showed that the higher the level of schooling, the greater the disagreement with this statement (Polychoric rho $=.204$ ).

\section{Discussion}

Considering Angolan students' positioning in a global view, a scenario of transmissive teaching and lack of resources emerges, pointing to similar demotivating learning experiences already identified in other countries across the world (Lyons, 2006). Many students frequently complain about repeated presentations of topics, the dictating or copying of 'correct knowledge', leaving no room for creativity (Obsorne, Simon, \& Collins, 2003; Batista, 2017). The authors Danaia, Fitzgeral and McInnon (2008) also identified a general dislike about decontextualized contents, associated to a global desire of closer links to everyday life, including more practical/ hands-on activities. For example, Vázquez and Manassero (2008) reported a students' desire for more opportunities to participate in class discussion. Technical reports from the MEA on the Angolan quality of education reflect similar concerns, assuming that the high number of students per class has been contributing to the general adoption of transmissive teaching methods which are not aligned with the development of competences and skills, like it is globally aimed, leading therefore to school unsuccess (MEA, 2014). This condition may have a particular negative effect on Angolan classes which integrate practical components, such as experimental sciences, namely Physics (Chimbalandongo, 2015). According to outputs from a research project focused on the evaluation of the impact of the curricular reform on Physics education, shortly designated as PIMEFA ("Projeto de Investigação para o melhoramento do Ensino da Física em Angola"), the high number of students per class and the lack of adequate laboratories and equipment in some schools preclude the possibility of experimentation, which makes this discipline more theoretical (INIDE, 2010).

Finally, differences of students' voice among $9^{\text {th }}$ grade and $7^{\text {th }}$ grade was analyzed in response to an extensive literature review conducted by Jenkins (2006) who concluded that research conducted so far on students' voice corresponds mainly to 'snapshots', lacking an evolutionary perspective. According to Angolan students' answers, they do fewer activities related to daily life, less activities in the laboratory and are involved less in their assessment along their school progress. A possible reason for this positioning may be a growing frustration within their progression from $7^{\text {th }}$ to $9^{\text {th }}$ grade, motivating a more critique posture, which reinforces the importance of overcoming the identified problems. Although previous studies already pointed out the major problems of Angolan educational contexts, the key contribution 
Maria da Graça BREGANHA, Betina da SILVA LOPES, Nilza COSTA. Using students' voice towards quality improvement of Angolan secondary physic classes

\begin{abstract}
PROBLEMS
OF EDUCATION

IN THE $21^{\text {st }}$ CENTURY Vol. 76, No. 3, 2018

296 of the present research is that young Angolan students also acknowledge these problems and report in first-hand how these problems affect their (motivation to) learning. Therefore, their voices constitute a useful instrument for educational management at school level and should be integrated more often in Angolan schools. Besides this national contribution, the fact that our study involved an evolutionary perspective of students' voices covers a research gap in international research in the topic and may guide further studies.
\end{abstract}

\title{
Conclusions
}

In this research Angolan students' voices from one public school about aspects of their physics classes were explored. Combining descriptive and inferential analysis allowed perceiving that inquired Angolan students (also) do have an opinion, and that this opinion changes over their schooling time. Reasons beneath these seem to be associated to a lack of resources and specific teaching learning and assessment innovative strategies/practices. Considering that students from the $9^{\text {th }}$ grade are in a pre-stage of choosing the knowledge domain of further studies (in science vs. not in science), these outputs, namely a possible growing of students' frustration towards the lack of resources, (more) contextualized learning, and integration in learning and assessment, should be considered at school management, taken into account at political level of education and should be more extensively explored in further research. The results concerning students' voice and its differences among grades, the last novelty of our research for (Angolan) educational contexts, as well as the problematization of what might sustain those differences, is of crucial relevance towards better quality and higher students' motivation in Physics education. Considering that gathering students' voices is still a rare practice in Angolan schools it is worth to mention that much work has to de done in order to familiarize students to answer to questionnaires and to express their true opinion. Researchers that are motivated to do similar investigations are recommended to sustain the application of the questionnaires with complemenatry strategies that help to assure that students understand what they are asked to do and that they are free to use their own opinion.

Finally, based on the obtained results the following recommendations are delineated: (i) continue to invest in gathering data about students' voice in each Angolan school, and use the obtained results for group discussions involving physics teachers from that school, the coordinator of that discipline and the head of the school, in order to help to identify problems and assets and to use the conclusions to prioritize actions; (ii) the discussion of students' voice at each school, and the obtained learning, should be disseminated at a larger scale through the Ministry of Education, namely through the Physics coordinator of each Angolan province; (iii) implement teacher development programs that enhance teachers' capacity in 'listening' to their students' and to use that voice in improving his/her practices at key-points identified by the students.

\section{Acknowledgements}

Work associated to this research was financially supported by the Portuguese Foundation for Science and Technology (FCT) under Grant SFRH/BPD/100330/2014 and UID/CED/00194/2013 co-funded by the POCH, by the European Social Fund and Portuguese National Funds from the Portuguese Ministry of Education and Science. The authors also thank the support given by INIDE.

\section{References}

Anderson, I. K. (2006). The relevance of science education as seen by pupils in Ghanaian junior secondary schools. Unpublished Doctoral Thesis. South Africa (Cape Town): University of Western Cape. Retrieved, 05/05/2018, from http://roseproject.no/network/countries/ghana/gha-anderson-thesis. pdf. 
Arroio, A. (2015). Is education the solution to problems in Africa? Problems of Education in the 21st Century, 64, 4-5.

Baptista, M. (2017). What is a good practice of science teaching? Some paths. Problems of Education in the 21st Century, 75 (3), 212-214.

Chimbalandongo, O. (2015). Avaliação das aprendizagens da disciplina de Física: do diagnóstico da situação à apresentação de uma proposta para a $10^{a}$ classe no Instituto Médio Agrário do Tchinvuguiro [Learning assessment of the discipline of Physics: From the diagnosis of the situation to the presentation of a proposal for the $10^{\text {th }}$ grade in the Instituto Agrario do Tchinvuguiro]. Unpublished master dissertation. Angola (Lubango): ISCED_Huíla.

Cook-Sather, A. (2006). Sound, presence and power: 'Student Voice' in educational research and reform. Curriculum Inquiry, 36, 359-390.

Danaia, L., Fitzgerald, M., \& McKinnon, D. (2008) Students' perceptions of high school science: What has changed over the last decade? Research in Science Education, 43, 1501-1515.

Delfin, D. (2014). Evolução da Educação e ensino em Angola (2002-2008) [Evolution of education and teaching in Angola]. Unpublished doctoral thesis. Portugal (Coimbra): University of Coimbra.

Fluter, J. (2007) Teacher development and pupil voice. The Curriculum Journal, 18 (3), 343-354.

Government of the Republic of Angola/GRA (2001). Integrated Strategy for the improvement of the Educational System. Republic of Angola (Luanda): Ministry of Education and Culture. Retrieved, 05/05/2018, from http://planipolis.iiep.unesco.org/sites/planipolis/files/ressources/angola estrategia_integrada_melhoria.pdf.

National Institute of Research and Development in Education [Instituto Nacional de Investigação e Desenvolvimento em Educação]//INIDE (2013). Programa de Física $-7^{a}, 8^{a}$ e $9^{a}$ classes. [Physics Program $-7^{\text {th }}, 8^{\text {th }}$ and $9^{\text {th }}$ grades]. Angola (Luanda): Editora Moderna.

INIDE (2010). Projeto de Investigação para a melhoria do Ensino da Física em Angola (PIMEFA) [Research Project towards the improvement of physic teaching in Angola - PIMEFA]. Angola (Luanda): INIDE.

INIDE (2012). Relatório do $3{ }^{\circ}$ Seminário Metodológico sobre a Melhoria do Ensino da Física em Angola [Report of the third methodological seminar about PIMEFA]. Angola (Luanda): INIDE.

Jenkins, E.W. (2006). The student voice and school science education, Studies in Science Education, 42, 49-88.

Liberato, E. (2014). Avanços e Recuos da Educação em Angola [Angola's education advances and setbacks]. Revista Brasileira de Educação, 19 (59), 1003-1031.

Lopes, B., Costa, N., \& Matias, B. F. (2016). Impact evaluation of two master courses attended by teachers: an exploratory research in Angola. Problems of Education in the 21st Century, 74, 49-60.

Lyons, L. (2006). Different countries, same science classes: Students' experiences of school science in their own words. International Journal of Science Education, 28 (6), 591-613.

McCallum, B., Hargreaves, E., \& Gipps, C. (2000). Learning: The pupil's voice. Cambridge Journal of Education, 30 (2), 275-289.

Ministry of Education of Angola [Ministério da Educação de Angola]/MEA (2008). Evolution of Education and Teaching in Angola (2002-2008). Angola (Luanda): MEA. Retrieved 05/05/2018, from http://www.med.gov.ao/VerPublicacao.aspx?id=587.

MEA(2014). Exame nacional 2015 da Educação para Todos: Relatório de Monitorização sobre Educação para todos. [National 2015 Report of Education for all: monitorization report]. Angola (Luanda): MEA. Retrieved, 05/05/2018, from http://unesdoc.unesco.org/images/0023/002317/231722por. pdf.

Oldfather, P. (1995). Introduction to 'learning from student voices'. Theory into practice, 43, 84-87.

Osborne, J., Simon S., \& Collins, S. (2003). Attitudes towards science: a review of the literature and its implications. International Journal of Science Education, 25 (9), 1049-1079.

Osler, A. (1994). The UN Convention on the Rights of the Child: some implications for teacher education. Educational Review, 46 (2), 141-50.

Santos Gouw, A., \& Bizzo Vincenzo, N. (2016). A Percepção dos jovens brasileiros sobre as suas aulas de Ciências. [Perception of young Brazilians about their science classes], Educar em Revista, 60, 277-292.

Singh, C. (2014). What can we learn from PER: Physics Education Research? The Physics Teaching, 52, 568- 569. 
Maria da Graça BREGANHA, Betina da SILVA LOPES, Nilza COSTA. Using students' voice towards quality improvement of Angolan secondary physic classes

OF ED

IN THE $21^{\text {st }}$ CENTURY

Vol. 76, No. 3, 2018

298

Sjoberg, S., \& Schreiner, C. (2010). The ROSE project: an overview and key findings. Retrieved 05/05/2018, from http://roseproject.no/network/countries/norway/eng/nor-Sjoberg-Schreineroverview-2010.pdf.

UNESCO (2016). Education 2030: Inchneon Declaration and Framework for Action towards inclusive and equitable quality education and lifelong learning for all. France (Paris): UNESCO.

Vázquez, A.,\& Manassero M.M. A. (2008). El declive de las actitudes hacia la ciencia de los estudiantes: un indicador inquietante para la educación científica [The decline of attitudes towards student science: A disquieting indicator for scientific education]. Revista Eureka sobre Enseñanza Y Divulgación de las Ciencias, 5 (3), 274-292.

Received: March 19, 2018

Accepted: May 19, 2018

\begin{tabular}{|ll|} 
Maria da. Graça Breganha & $\begin{array}{l}\text { PhD Student, INIDE - National Institute for Research and Development in Educa- } \\
\text { tion, Luanda, Angola. } \\
\text { E-mail: mariadagraasoaresbreganha@yahoo.com.br } \\
\text { Website: https://orcid.org/0000-0003-3520-3521 }\end{array}$ \\
\hline Betina da Silva Lopes & $\begin{array}{l}\text { PhD in Education (Didactics and Curricular Development), Post Doctoral Re- } \\
\text { search Fellow \& Invited Assistant, CIDTFF, University of Aveiro \& Department of } \\
\text { Life Science, University of Coimbra, Portugal. } \\
\text { E-mail: blopes@ua.pt } \\
\text { Website: https://orcid.org/0000-0003-0669-1650 }\end{array}$ \\
\hline Nilza Costa & $\begin{array}{l}\text { PhD, Full Professor and Senior Researcher in Sciences/Physics Education, Uni- } \\
\text { versity of Aveiro, CIDTFF, Aveiro, Portugal. } \\
\text { E-mail: nilzacosta@ua.pt } \\
\text { Website: https://orcid.org/0000-0002-1707-9697 }\end{array}$
\end{tabular}

